\section{En kamp mot vindmøller}

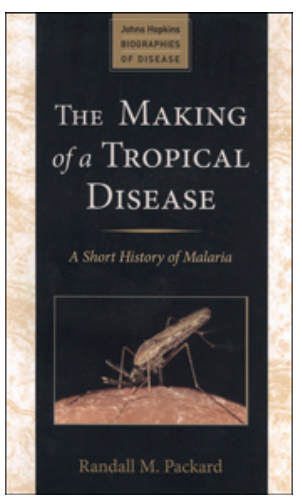

Randall M. Packard

The making of a tropical disease

A short history of malaria. $296 \mathrm{~s}$, tab, ill. Baltimore, MD: The Johns Hopkins University

Press, 2011. Pris USD 25

ISBN 978-1-4214-0396-0

En historiker har skrevet boken. Selv om eieren av problemet er fattigfolk i sør, er nok boken først og fremst skrevet til oss som sitter på utsiden og observerer problemet. Den kan være interessant for bl.a. helsebyråkrater, bistandsarbeidere og beslutningstakere i den industrialiserte delen av verden.

Forfatterens interesse for malaria sprang ut fra hans eget møte med febersyke småbarn på en liten klinikk i Mulanda i Uganda tidlig i 1960-årene. Mange av disse døde fordi de kom for sent til behandling eller fordi det ikke fantes riktig behandling på stedet.

Det er åtte kapitler, en kort innledning og konklusjon, en omfattende referansedel og en indeks. På knappe 300 sider forsøker forfatteren å gi en oppsummering av malariaens globale historie og hvordan den har vært gjenstand for gjensidig påvirkning mellom vert, vektor og parasitt.

Mennesker har gjennom påvirkning av naturen enkelte steder skapt fremvekst og andre steder utryddet sykdommen. Sosiale, politiske og økonomiske faktorer har også lagt til rette, eller vært en hindring, for spredning.

Historien begynner i Afrika for 10000 år siden, hvor malaria mest sannsynlig hadde sitt opphav blant bønder som levde i tropiske skoger i Sub-Sahara. I andre kapittel beskriver forfatteren ekspansjonen av malaria nordover til Europa og den nye verden, og hvordan og hvorfor den forsvant fra disse områdene midt på 1700 -tallet. I tredje og fjerde kapittel forsøker forfatteren å gi svar på hvorfor malaria i tropiske og subtropiske områder av Afrika, Asia, Mellom- og Sør-Amerika og Sør-Italia ikke hadde den samme skjebnen, men ble vedvarende og i mange områder ekspanderte gjennom 1800- og 1900-tallet. Sykdommen gikk fra å være en global sykdom til å begrense seg til å bli en tropisk sykdom, derav navnet på boken.

Fattigdom, både nasjonalt og individuelt, er både en årsak og virkning av sykdommen. Forfatteren argumenterer for en kombinasjon av vitenskapelige og sosiale fremskritt for å kunne få kontroll over sykdommen. Dette innebærer både å opprettholde nåværende malariaprogram, utvikle en malariavaksine og nye antimalariamedisiner og endre samfunn og internasjonal politikk, slik at man kan få en bærekraftig og vedvarende forbedring av malariasituasjonen.

Packard mener at problemet ikke kan løses innenfra, men at man må ha hjelp utenfra, bl.a. ved sletting av u-landsgjeld, bilateral handel, fjerning av subsidiert landbruk i rike land, utdanning og oppbygging av lokalt helsevesen. Således er det kanskje riktig med en bok skrevet til beslutningstakerne.

Boken er interessant og velskrevet, veldokumentert og balansert, til tross for at forfatteren aldri legger skjul på sine meninger og intensjonen bak. Jeg anbefaler den til alle med interesse for internasjonal helse, og spesielt til dem som planlegger å starte en ny malariakampanje.

Tove Heger

Avdeling for anestesi

Klinikk for kirurgi og akuttmedisin - Møre og Romsdal

Ålesund

\section{Oversiktlig om ernæring}

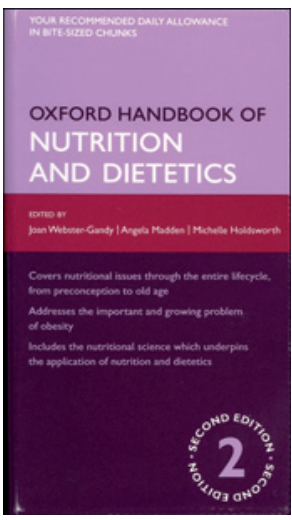

Joan Webster-Gandy, Angela Madden,

Michelle Holdsworth, red.

0xford handbook of nutrition and dietetics

818 s, tab, ill. 2. utg. Oxford: Oxford University

Press, 2012. Pris GBP 30

ISBN 978-0-19-958582-3

Oxford handbook of nutrition and dietetics er myntet på leger, sykepleiere og kliniske ernæringsfysiologer som arbeider med ernæringsproblematikk. Den er skrevet av tre kliniske ernæringsfysiologer og bærer preg av det. Jeg tror leger vil synes det er feil proporsjon i oppbyggingen av flere kapitler. For eksempel er det ved ulike sykdommer brukt uforholdsmessig mye plass på å fortelle hva sykdommen er og beskrivelse av symptomer. Dette vil kanskje være nyttig for andre yrkesgrupper, men er en del av grunnutdanningen for leger, noe som gjør at boken appellerer mindre til leger enn til annet helsepersonell.

Dette er og blir en håndbok i ordets rette forstand, i lommeformat og med plastpermer. Ordbruken er kort og konsis. Stoffet spenner over hele livssyklus, fra før unnfangelse til høy alder, gjennom 38 hovedkapitler og nesten 780 sider. Da sier det seg selv at dybden $\mathrm{i}$ innholdet blir begrenset. Boken er bygd opp på evidensbasert medisin, men spesielt for ulike vitaminer og sporstoffer er kunnskapen i stadig endring, og en del av det som beskrives, er noe kontroversielt. Forfatterne er briter. Behandlingstradisjon, hva som er sunt kosthold, og hvor mye alkohol som kan drikkes uten at det er helsefarlig, er det tydeligvis faglig uenighet om mellom Storbritannia og Norge.

Tabellene er for det meste illustrative og oversiktlige, mens figurene er i enkleste laget. Det finnes mange behandlingsalgoritmer som kan være til god hjelp i den kliniske hverdagen.

Referansene er få, men et eget appendiks refererer til mange og nyttige nettadresser. Videre er det en god og omfattende indeks.

Boken egner seg best for kliniske ernæringsfysiologer og sykepleiere med spesiell interesse for faget. Kunnskapen blant norske leger innen fagfeltet ernæring kan med fordel bli bedre, og av den grunn bør boken finnes på alle avdelinger.

\section{Øivind Irtun}

Avdeling for gastroenterologisk kirurgi

Universitetssykehuset Nord-Norge 